\title{
FAST-FLAIR 法におけるフラッシング現衷の検討
}

\section{The Study of Flashing Phenomenon in FAST-FLAIR Method}

\author{
日本医科大学附属病院 O浅野 恭司

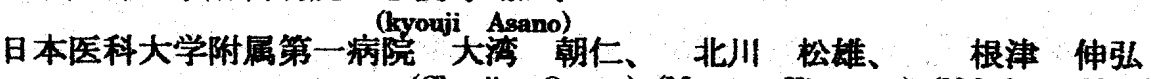 \\ (株) 島津製作所・医用応用技骕部清水 (Matsuo Kitagawa) (Nobuhiro Nezu) \\ (Shimi水 公治
}

【目的】 FAST-FLAIR 法に抽い、瞵接するスライス問で極端に信号強度の変化する現象（以下、フラッシング） がある。この現象は、組織間コントラストにも影零すると予湘される。今回、我々は、フラッシングは、クロスト

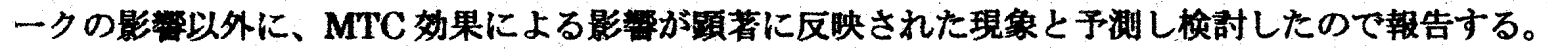

【力法】水、Baby Oil、PVAゲルファントムを使用し、

1.スライスギャップの違いによる信号强度の変化

2. 励起時間差による信号強度の变化

3. RF-Dutyバランスによる信号強度の変化

について検討した。

【使用機器】岛律社彆 MRI 装是 MAGNEX150XP

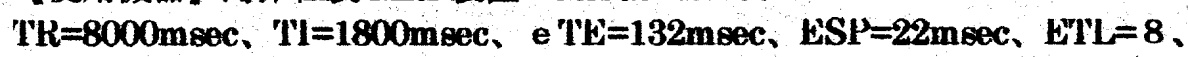

Matrix $=256 \times 256 、 \mathrm{NEX}=1 、 \mathrm{FOV}=230 \mathrm{~mm}$ 、Width $=7 \mathrm{~mm}(5 \mathrm{~mm}) 、$ Pitch $=8.5 \mathrm{~mm}$

【結果及び考察】スライスギャップをスライス厚の 50\%以上大きくするとクロストークの影制は抑制することが できた。しかしこの時にも PVA での信号率の低下は牫存し、MTC 効果の影第が示晙された 励起時間差 を持つことで Oil におけるクロストークの影掣は㧕制できたが、PVA においても T1 緩和時間の長い水同様の信号 の回復を示し、クロストークの影繁が㧕制されても MTC 効果の影灀が関与しているものと考えられた

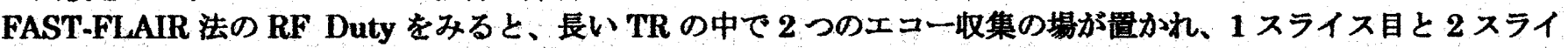
ス目の励起開始の時間間淂(スライスインターバル)が ETL、ESPに依存した最短時間で列されている。このエコ 一収集の場の RF Duty が前半と後半とで不均等な状態で列されているときに信号強度のバラッキが目立つ。 RF

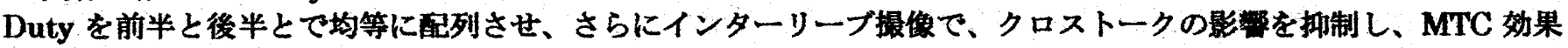
の影輍を隣接するスライス間で均等な状態にし、冬スライス間の信号強度差をできるだけスムースにすることを考 えた。TI,ETL,ESP、スライス数から RF Duty を均等に配列するスライスインターバルを算出し、設定する。この ときスライス数は均等列列であることから偶数スライスが望ましいと考えた (表 1)。この方法により、各スライ ス間での信号強度の極端な差は無くなり、MTC 効果の影盤も勾一化し、臨床やボランティアにおいてもフラッシ ングは認められなくなった

【結語】フラッシング現象は、組織問コントラストにも影警する現象であった、その原因としてクロストークと MTC 効果が関与していることがファントム実験で確認できた。クロストークは、インターリーブ撮像法を使用して Oil と PVA では㧕制可能であった、T1 緩和の辰い自由水ではクロストークの影警は残存するが、水抑制の FLAIR で は、CSF の信号を抑制するので、閣題にならない。PVA における MTC 効果の影稚は、インターリーブ撮像法に おいて RF Duty を均等配列することで隣接するスライス間で均一化することができた。常検査においてTRやTI、 スライス数を変更する祭にはフラッシングが発生しないような RF-Duty を均等配列するスライスインターバルの 設定が必要であり、この事は,FAST-IR 法等においても同様なことと考えられ注意する必要がある。

不均等蚂列された RF Duty
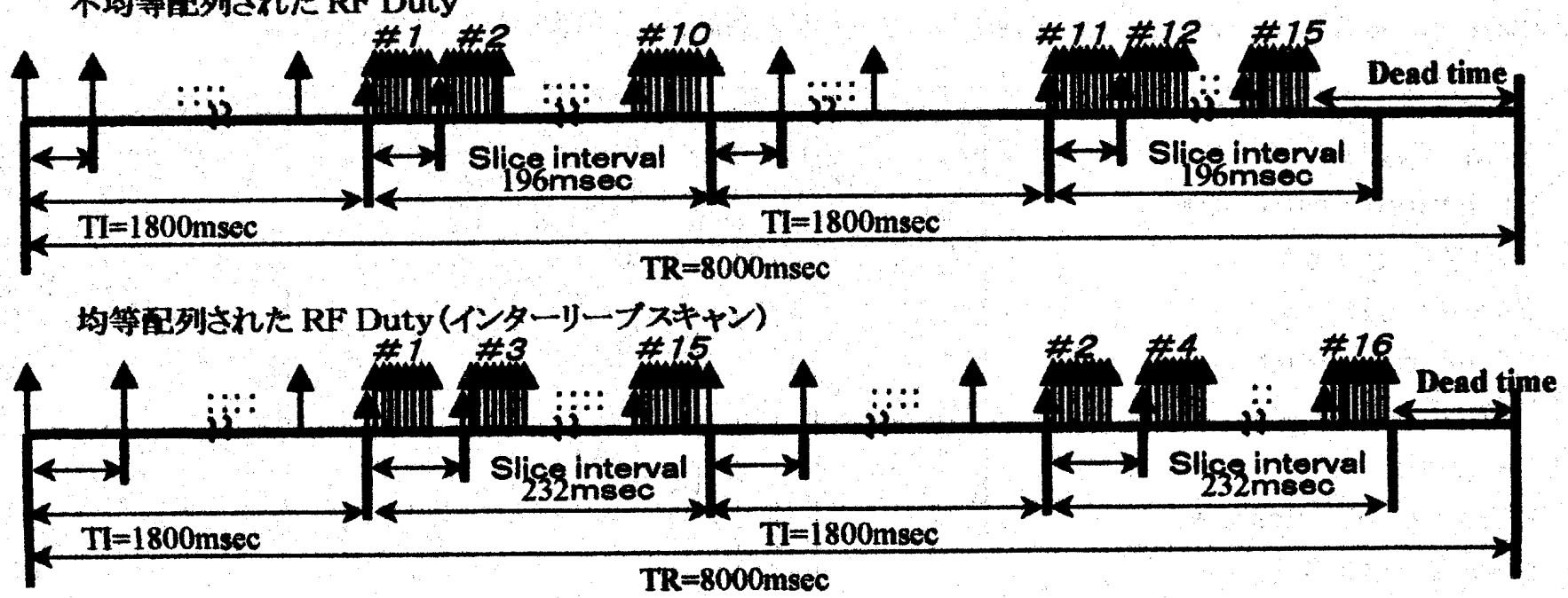